\begin{tabular}{|c|c|c|}
\hline Beitr. Ent. & Keltern & ISSN 0005-805X \\
\hline $\mathbf{5 8}(2008) 2$ & S. $227-237$ & 15.11 .2008 \\
\hline
\end{tabular}

\title{
A new species of Eufriesea from Jalisco, México, with a key to Mexican species of the genus
}

\section{(Hymenoptera: Apidae)}

With 10 figures

\author{
R. Ayala and Michael S. Engel
}

\section{Summary}

A new species of the orchid bee genus Eufriesea Cockerell (Apidae: Apinae: Euglossini) is described and figured. Eufriesea micheneri sp. $\mathbf{n}$. is generally similar to E. caerulescens (LePELETIER DE SAINT FARGEAU) with is dark blue integument and purple iridescence but differs by its black pubescence, dark wings, and in the male by its green facial integument and terminalia. The new species is known from the Sierra del Tuito in Jalisco State, México, a western part of the Transverse Volcanic Belt. A key for the Mexican species of Eufriesea is provided in English and Spanish.

\section{Zusammenfassung}

Es wird eine neue Art der Prachtbienengattung Eufriesea Cockerell (Apidae: Apinae: Euglossini) beschrieben. Eufriesea micheneri sp. n. ähnelt allgemein E. caerulescens (Lepeletier de SAINT Fargeau) mit ihrem dunklen blauen, purpurn irisierendem Integument, unterscheidet sich aber durch die schwarze Behaarung, dunkle Flügel und beim Männchen durch das grüne Gesicht und die Terminalia. Die neue Art ist bisher von der Sierra del Tuito im Staat Jalisco, Mexiko, bekannt, einem westlichen Teil des Transverse Volcanic Belt. Ein Bestimmungsschlüssel der mexikanischen Eufriesea-Arten ist in Englisch und Spanisch angefügt.

\section{Resumen}

Se describe una nueva especie de abeja del género Eufriesea Cockerell (Apidae: Apinae: Euglossini) con integumento azul oscuro e iridiscencia morada, similar en apariencia a Eufriesea caerulescens (Lepeletier DE SAInt Fargeau), de la cual puede ser fácilmente diferenciada por presentar pubescencia negra, alas más oscuras y en el caso de los machos el área facial con integumento verde metálico. Esta especie se conoce únicamente para la Sierra del Tuito, en el extremo más Oeste del Eje Volcánico Transversal, en el estado de Jalisco, México. Se incluye una clave para el reconocimiento de las especies mexicanas en ingles y español.

\section{Key Words}

Hymenoptera, Apoidea, Anthophila, Euglossini, taxonomy, México. 


\section{Introduction}

Bees of the genus Eufriesea Cockerell (Euglossini) are readily recognized by their large, robust size and frequently metallic coloration which ranges from blue or green with yellow, to reddish or purple iridescence (e.g., Figs 1-2). The genus, like its relatives in the Euglossini, is also noteworthy for its role in orchid pollination. Euglossine males visit orchid flowers, among others, to collect essentials oils which are then carried and modified in their hind tibiae, and are presumably used as attracts for females (e.g., Kimsey, 1980, 1982; Dressler, 1967, 1968a, 1968b; Roubik \& Hanson, 2004; Michenter, 2007). Eufriesea comprises about 60 species confined to the Neotropical region, most of which occur in South America (RAmírez et al., 2002). The genus was revised by KIMSEY (1982) who reported six species from México, one of these being Eufriesea caerulescens (Lepeletier de SAINT FARGeAu), a species similar in overall appearance to the taxon treated in the present study. For those species occurring in México there are few distributional records for those comprising the caerulescens species group. Apparently the distribution for the two species of this group in México follows that of the tropical dry forest, or the pine and oak forest, between sea level and about $1500 \mathrm{~m}$ elevation. Herein we provide new information on species in this group in México with the description of a new species that may be confused easily with E. caerulescens.

\section{Material \& Methods}

The first specimen encountered for the new species reported herein was collected during the fieldwork of the PCAM project (El Programa Cooperativo sobre la Apifauna Mexicana). Additional specimens were later found in the Colección Entomológica, Centro de Estudios en Zoología, CUCBA, Universidad de Guadalajara, México (CEGM) or were collected as part of the dissertation research of Charlotte SKOV at the University of Florida. Specimens were subsequently distributed across the Instituto de Biología, México City, México (UNAM); Insect Collection of the Chamela Field Station, Chamela, México (IBUNAM); the Snow Entomological Collection, Division of Entomology, University of Kansas Natural History Museum, Lawrence, Kansas, USA (KSEM); and the Bee Biology and Systematics Laboratory at Utah State University, Logan, Utah, USA (EMUS). Morphological terminology for the description follows that of ENGEL (2001) and Michener (2007), with the abbreviations $S$ and T replacing metasomal sternum and metasomal tergum, respectively. Illustrations of the genitalia and sterna were made using a camera lucid mounted on an Olympus SZH10 dissecting microscope. Photomicrographs were made using Nikon D1x digital camera attached to an Infinity K-2 long-distance microscopic lens. A key to Mexican species of Eufriesea was prepared by modifying the keys of KIMSEY (1982).

\section{Systematics}

Eufriesea micheneri, sp. n. (Figs 1-9)

\section{Diagnosis:}

The new species is similar in appearance and coloration to E. caerulescens, but males are separable by the dark blue integument with strong purple iridescence on the vertex, mesosoma, legs, and metasoma; the generally dark fuscous pubescence and wings (Figs 1-2); the typically green 
integument of the facial area (Fig. 1), contrasting with the dark blue and purple on the remainder of the integument; the metatibiae with a subapical projection on near the inner margin of the anterior surface which delimits the upper border of a slightly depressed area (Fig. 3); and in structure of the male terminalia (Figs 4-9).

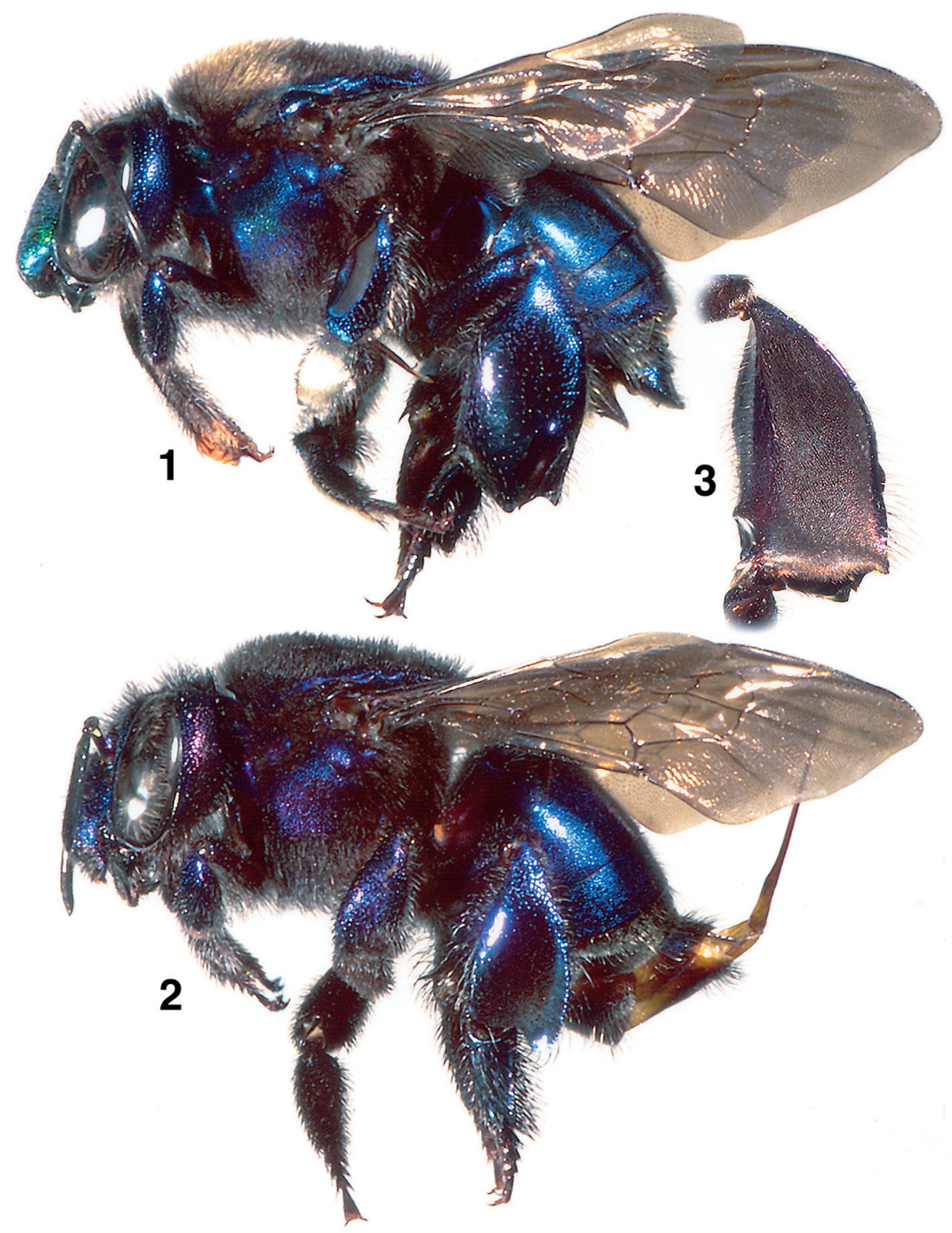

Figs 1-3: Eufriesea micheneri sp. n. - 1 lateral aspect of male. -2 lateral aspect of female. -3 inner view of male metatibia (note the subapical projection near the inner border of the anterior surface). 


\section{Description:}

$\sigma^{*}$ : Total body length $17.8 \mathrm{~mm}$; forewing length $16.30 \mathrm{~mm}$, width $5.30 \mathrm{~mm}$. Head. Head wider than long, length $5.50 \mathrm{~mm}$, width $6.30 \mathrm{~mm}$. Glossa extending to second metasomal sternum. Labrum with two longitudinal, sublateral carinae that converge apically, with an elevated medial carina. Clypeus and facial area strongly and coarsely punctured, integument between punctures shining and polished, not granulose or imbricate; with weak sublateral and medial ridges on slightly elevated. Compound eye length $2.07 \mathrm{~mm}$, width $1.49 \mathrm{~mm}$; upper interorbital distance $2.60 \mathrm{~mm}$, lower interorbital distance $3.20 \mathrm{~mm}$, interorbital distance at tangent of upper third of compound eye length $3.57 \mathrm{~mm}$; ocellocular distance $0.60 \mathrm{~mm}$; posterior distance between lateral ocelli $0.64 \mathrm{~mm}$, distance between medial and lateral ocelli $0.29 \mathrm{~mm}$, width of medial ocellus $0.39 \mathrm{~mm}$, distance between medial ocellus and posterior tangent of ocellar triangle $0.44 \mathrm{~mm}$; interocellar furrow present (sensu ENGEL, 1999). Scape length $1.96 \mathrm{~mm}$, width $0.35 \mathrm{~mm}$; length of flagellum $4.60 \mathrm{~mm}$, width $0.40 \mathrm{~mm}$; distance between antennal torulus and compound eye $0.69 \mathrm{~mm}$; distance between antennal toruli $1.08 \mathrm{~mm}$.

Mesosoma. Mesoscutal width $5.54 \mathrm{~mm}$, length $4.60 \mathrm{~mm}$; mesoscutum with dense, coarse punctures, space between punctures very small. Tegula with dense, shallow punctures, impunctate and shining on posterior and lateral margins. Mesoscutellar width $4.50 \mathrm{~mm}$, length $2.30 \mathrm{~mm}$; mesoscutellum with dense punctured, distance between punctures always smaller as the diameter of the punctures; upper surface of mesoscutellum rounded in lateral view, with two sublateral elevations defined by mediolongitudinal sulcus; posterior-lateral angle of mesoscutellum rounded. Metanotal integument smooth. Jugal comb present at base of hind wing, setae of jugal comb longer than width of jugal lobe. Metatibia with depression on distal part of anterior surface near apical angle, depression proximally delimited by subapical projection (Fig. 3); metabasitarsus with strong elevation on inner surface near base.

Metasoma. Terga imbricate and with small, homogeneous punctures; dorsal-facing surface of T1 slightly longer medially than maximal width of forewing marginal marginal cell, with anteriorfacing and lateral surfaces smooth and shining. Apicalmost margins of T2-4 impunctate. Apical margin T6 slightly projected, with acute apex. Apical margin T7 medially depressed. Sterna imbricate. Hidden sterna and genitalia as depicted in figures 4-9.

Coloration. Mandible black with some metallic green, blue, and purple iridescence on basal third. Facial area and clypeus metallic green or bluish green, remainder of head dark metallic blue. Part of labrum, vertex, gena, mesoscutellum, metanotum, propodeum, and mesosomal pleura dark metallic blue with purple iridescence. Pronotum dark metallic blue. Majority of mesoscutum metallic blue and greenish blue except posterior fourth dark blue with purple iridescence. Antenna and tarsi black. Wing membranes darkly infuscate (Fig. 1), with some faint opalescence; veins black. Metasoma dark metallic blue with faint purple iridescence.

Pubescence. Clypeus and facial area with off white or grey pubescence. Vertex, gena, pronotum, mesepisternum, mesoscutellum, and metasomal terga with dark fuscous nearly black setae. Mesoscutum with brown setae predominant on anterior half of surface, anteriormost margin and remainder of surface with black setae. Legs with fuscous nearly black setae except outer surface of mesotibia with dense white setae. Metasomal S3-5 with abundant white or off white setae, apices of such setae curled.

ㅇ: As described for the male except as follows: Total body length $17.50 \mathrm{~mm}$; forewing length $14.67 \mathrm{~mm}$, width $4.96 \mathrm{~mm}$. Head. Head wider than long, width $5.99 \mathrm{~mm}$, length $5.03 \mathrm{~mm}$. Glossa extending to first metasomal sternum. Mandible with distal half of inferior margin 
rounded (but not strongly rounded as in E. caerulescens); inferior tooth (apical) largest, projecting beyond medial tooth, forming an orthogonal (i.e., $90^{\circ}$ ) notch between teeth. Labrum with medial line elevated, larger than sublateral carinae. Clypeus rounded, with strong, coarse punctures, integument between punctures smooth and shining, not granulose or imbricate as in E. concava (FrIESE) or E. mexicana (MocsárY). Supraclypeal area and frontal line slightly elevated between interantennal area and basal margin of clypeus. Compound eye length $4.23 \mathrm{~mm}$, width $1.71 \mathrm{~mm}$; upper interorbital distance $2.86 \mathrm{~mm}$, lower interorbital distance $3.20 \mathrm{~mm}$, interorbital distance at tangent of upper third of compound eye length $3.63 \mathrm{~mm}$; ocellocular distance $0.74 \mathrm{~mm}$, ocellocular space slightly depressed; posterior distance between lateral ocelli $0.73 \mathrm{~mm}$, distance between medial and lateral ocelli $0.31 \mathrm{~mm}$, width of medial ocellus $0.31 \mathrm{~mm}$, distance between medial ocellus and posterior tangent of ocellar triangle $0.49 \mathrm{~mm}$; vertex posterior to interocellar furrow elevated. Scape length $1.94 \mathrm{~mm}$, width $0.29 \mathrm{~mm}$; length of flagellum $3.88 \mathrm{~mm}$, width $0.34 \mathrm{~mm}$; distance between antennal torulus and compound eye $0.80 \mathrm{~mm}$; distance between antennal toruli $1.11 \mathrm{~mm}$.

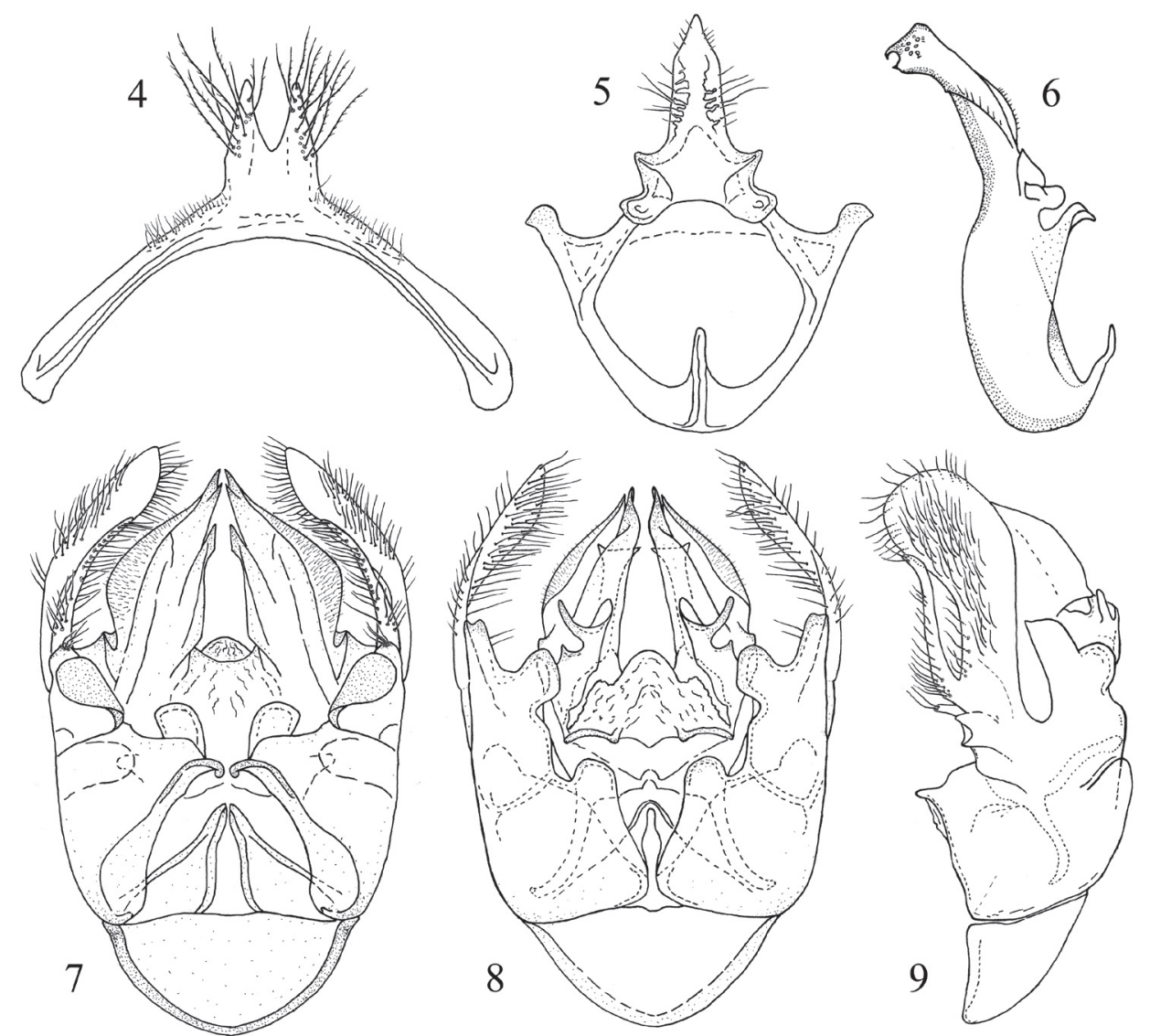

Figs 4-9: Male terminalia of Eufriesea micheneri sp. n. -4 seventh metasomal sternum. -5 eighth metasomal sternum, dorsal aspect. -6 eighth metasomal sternum, lateral aspect. -7 genital capsule, ventral aspect. - $\mathbf{8}$ genital capsule, dorsal aspect. $\mathbf{- 9}$ genital capsule, lateral aspect. 
Mesosoma. Mesoscutal width $5.37 \mathrm{~mm}$, length $4.23 \mathrm{~mm}$; mesoscutellar width $4.26 \mathrm{~mm}$, length $1.83 \mathrm{~mm}$. Mesoscutum and mesoscutellum with dense, coarse punctures. Tegula uniformly punctuate, with narrow lateral margin interrupted in anterior third. Mesoscutellum slightly rounded in lateral view, with weak medial depression along; posterolateral angles rounded. Metatibia length $5.70 \mathrm{~mm}$, width $1.83 \mathrm{~mm}$.

Coloration. Integument of head, mesosoma, legs, and metasoma dark metallic blue and purple, with strong purple iridescence (Fig. 2). Green of facial area weaker than in male. Mandible black, with dark blue restricted to basal third. Mesoscutum with dense black pubescence, partially obscuring integument. Lateral surface of mesosoma with black pubescence.

Pubescence. Generally dark fuscous, nearly black; particularly dense on mesoscutum, partially obscuring integument. Metasomal T5 with white setae laterally; sterna with black pubescence.

\section{Type material:}

Holotype ơ, labeled, "México, Jalisco, Mascota, 17-VII-1989 [17 July 1989], col. R. Ayala, ex: Salvia sp.". The holotype is deposited in the Instituto de Biología (UNAM). Paratypes: $6 o^{\star} o^{\star}, 2$ 우 웅, with same data as holotype; $4 \sigma^{\star} o^{\star}$, labeled, "México. Jalisco, Talpa, 18-VII-1989 [18 July 1989], col. R. Ayala, ex: Salvia sp.”. 2 ơ ơ , labeled, "Mexico, Jalisco, Mascota, 17-VII-1989 [17 July 1989], J. Quezada". $10^{\star}$, labeled, "Mexico, Nayarit, km 11 La Nesa, Sta. Teresa, 21-X-1989 [21 October 1989], A. Cadena”. Paratypes are distributed among IBUNAM, KSEM, and EMUS.

\section{Additional material:}

$160^{\top} o^{\star}$, labeled, "Jalisco, Mascota, km 107, Ameca-Mascota, BEP 20²7"N, 10445"W, 1430 m, 14-VII-2004 [14 July 2004], J. Cortés-Aguilar" (in CEGM). 1 o', labeled, "Jalisco, Tequila, Volcán de Tequila, BE-BMM, 1800 m, 19-VII-1995 [19 July 1995], H. Fierros" (in CEGM). 1 o", labeled, "Jalisco, Ameca, Cerrote Ameca, BTC, 1520 m, 9-VIII-1994 [9 August 1994], H. Fierros" (in CEGM). 1 o", labeled, "Jalisco, Cocula, Microondas Quililla, B. Encinos, 22-VI-1994 [22 June 1994], 1900 m, H. Fierros" (in CEGM). 5 o o , labeled, "Jalisco, Mascota, Camino a San Sebastián del Oeste, BEP, 1628 m, 14-VII-2004 [14 July 2004], J. Cortes-Aguilar” (in CEGM). $1 \mathrm{o}^{\star}$, labeled, "Canyon N. Ajijic, Jal. [Jalisco], Mex. [Mexico], 5400 ft., 22 July 1964, W.L. Nutting \& sons, Scrub forest" (in KSEM). 1 o", labeled, "Mexico: km 12, Autopista México-Cuautla, Tepoztlán, Morelos, 30/06/1996 [30 June 1996], I. Hinojosa (HD-755), 14:20h, $1650 \mathrm{~m}, 18^{\circ} 58^{\prime} 24^{\prime \prime} \mathrm{N}, 99^{\circ} 4^{\prime} 57^{\prime \prime} \mathrm{W}$, cultivo de temporal [crop field], s/Podranea ricasoliana [ex: Podranea ricasoliana] - 02290" (in MZFC). 1 o $^{\star}$, labeled, "Mexico: km 12, Autopista MéxicoCuautla, Tepoztlán, Morelos, 13/07/1996 [13 July 1996], O. Yánez (OY-752), 13:30h, 1650 m, $18^{\circ} 58^{\prime} 24^{\prime \prime N}, 99^{\circ} 4^{\prime} 57^{\prime \prime} \mathrm{W}$, cultivo de temporal [crop field], s/Podranea ricasoliana [ex: Podranea ricasoliana] - 02310” (in MZFC).

\section{Etymology:}

The specific epithet is a patronymic honoring our friend and colleague Charles D. Michener, in recognition of his contributions to melittology and in celebration of his $90^{\text {th }}$ year (as of 22 September 2008).

\section{Distribution and phenology:}

The overall morphology of the new species is similar to that of E. caerulescens (sensu KIMSEY, 1982) which is also occurs in the same geographical region but is known only from the lowlands, near to the coast of the Pacific Ocean and in areas with dry tropical forest, as well as in the Central 
Depression of México (Balsas River Depression). In contrast, E. micheneri sp. n. is restricted to the mountains of Jalisco and in pine and oak forests at an elevation over $700 \mathrm{~m}$, in western parts of the Transverse Volcanic Belt (Fig. 10). Naturally, the distribution of E. micheneri sp. n. is perhaps a bit broader than what is presently known. Future collecting should focus in Michoacán State, were the species likely occurs, along of the southern slopes of the Transverse Volcanic Belt. The available collecting times for the species suggest that it is most active from late June through early August, during the early part of the rainy season. Eufriesea micheneri sp. $\mathrm{n}$. is apparently an efficient buzz pollinator of Senna sp. (Caesalpiniaceae = Leguminosae), abundant at the type locality.

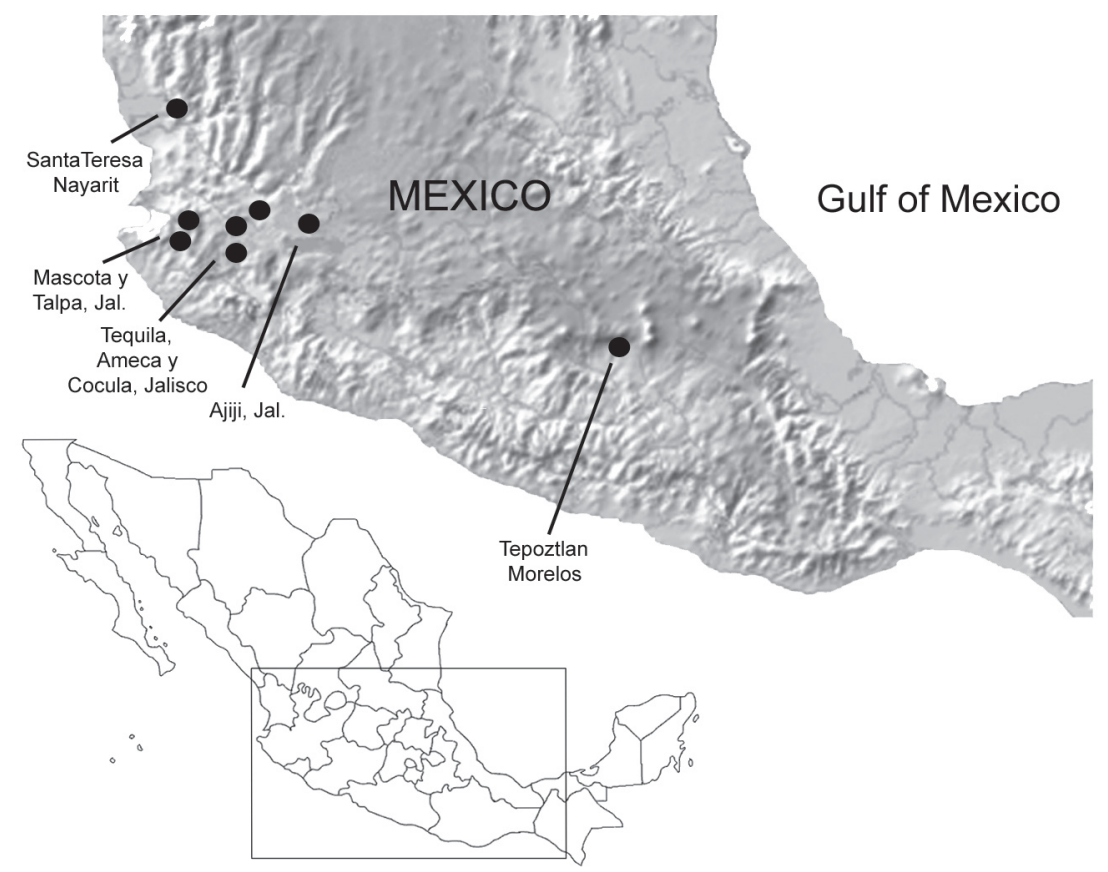

Fig. 10: Map of México and Jalisco State, with the current collection localities for Eufriesea micheneri sp. n. indicated by black circles.

\section{Comments:}

The species E. simillima (Moure \& Michener) (in Moure, 1965) from the western slopes of the Cordillera of Chihuahua was considered a synonym of E. caerulescens by KIMSEY (1982). She believed that the former form merely represented a color variant of the latter. Indeed, the morphology of the distal anterior angle of the male metatibia is the same in both taxa, further suggesting that E. simillima is simply a form of color variation in a more widespread species. An extreme variation in color occurs in specimens collected on Islas Marias of Nayarit State, located $112 \mathrm{~km}$ from the coast. In this population all individuals exhibit a strikingly dark blue integument that appears almost black (only female specimens are presently known). We generally agree with this interpretation of E. simillima and E. caerulescens, noting that a similar pattern occurs in E. micheneri sp. n., with variation in coloration even along the limited distribution presently known for this species. Specimens from the Sierra del Tuito, a mountainous area on the western extreme of the Transverse Volcanic Belt in México, are all similarly dark blue in overall 
color. In some males found in localities more toward the center of México, however, they lack the metallic green integument and highlights of the face, while the metatibial (Fig. 3) and terminalic morphology remains identical across the populations.

\section{Key to Mexican Species of Eufriesea}

[Females of E. pallida (Kimsey) are unknown.]

1 Female: antennae with 12 articles; metasoma with six visible terga; metatibia flattened, developed into corbicula ... 2

- $\quad$ Male: antennae with 13 articles; metasoma with seven terga; metatibia inflated with posterior slit and no corbicula 8

2(1) Glossa long, reaching S2 or beyond, two or more times as long as compound eye length

Glossa short, not reaching S2, length less than twice compound eye length 3

3(2) Head and mesosoma dark blue or dark purple; forewing medial cell not darker than remainder of wing [Mexico to northern Costa Rica] E. mexicana (MocsárY)

- Head and mesosoma black; forewing medial cell darker than remainder of wing [Mexico to Brazil] E. surinamensis (LinNaEus)

4(2) T3 black, purple, blue, or dark greenish, half with black setae and half with white setae

T3 brassy, coppery, yellowish green, or scarlet …........................................................ 7

5(4) Head and mesosoma black, sometimes with some bluish highlights (T2-6 blue or purple greenish, with yellow setae; clypeus depressed on either side of medial ridge) [México to western Panamá] E. rugosa (FriEse)

- $\quad$ Head and mesosoma bright blue, purple, or dark green to yellowish green ................... 6

6(5) Mandible blue and green on basal third, as on remainder of facial area; mesoscutum and mesoscutellum with abundant pubescence, setae not dense [México to Honduras]

E. caerulescens (LePELETIER DE SAINT FARGEAU)

- Mandible black on basal third, with only a little dark blue coloration; mesoscutum and mesoscutellum with abundant and dense black pubescence (NотE: the mesoscutellum in some specimens has blue darker than that on mesoscutum, and with distinct purple iridescence) [west-central México]

E. micheneri sp. n.

7(4) Clypeus with sublateral ridges, without medial ridge, area between sublateral ridges concave, impunctate and polished [México to southeastern Brazil] E. concava (FRIESE)

- Clypeus with sublateral and weak medial ridges [México to southeastern Brazil] E. mussitans (FABRICIUS)

8(1) Head, mesosoma, and metasoma concolorous, usually metallic blue or dark green ....... 9 Head and mesosoma different in coloration from that of metasoma (typically with T1 dark and T2-5 with yellow or golden shining pubescence, sometimes with blue or purple iridescence) 
9(8) Facial area green and greenish blue like remainder of head and body; pubescence white to off white on gena and mesosomal pleura [México to Honduras]

E. caerulescens (Lepeletier de SAINT FARGEAU)

- Facial area with integument green, bluish green, or greenish blue, contrasting with remainder of dark blue and purple integument on remainder of head and body; pubescence dark fuscous to black on gena and mesosomal pleura [west-central México]

E. micheneri sp. n.

10(8) Glossa extending beyond S2

Glossa short, not extending to S2

11(10) Vertex and anterior half of mesoscutum with pale pubescence [southern México]

E. pallida (KIMSEY)

Vertex with black pubescence, contrasting with brown or pale brown setae on anterior half of mesoscutum

12(11) Forewing medial cell not darker than remainder of wing; S8 produced into a single, elongate apical point in lateral view [México to northern Costa Rica] ..... E. mexicana (Mocsáry)

- $\quad$ Forewing medial cell darker than remainder of wing; S8 produced into two apical points in lateral view [Mexico to Brazil] E. surinamensis (Linnaeus)

13(9) Clypeus with strong sublateral ridges; surface of metatibia black, without metallic iridescence

Clypeus without sublateral ridges; metatibia with exterior surface reddish brown, remainder of tibia black [México to western Panamá] E. rugosa (FRIESE)

14(13) Clypeus without medial ridge, area between sublateral ridges concave and impunctate; mesotibia with setal brush poorly developed [México to southeastern Brazil]

E. concava (FRIESE)

Clypeus with medially punctate, with ridge or welt; mesotibia with setal brush well developed [México to southeastern Brazil] E. mussitans (FABRICIUS)

Clave para las Especies Mexicanas del Eufriesea

1 Hembras: antenas con 12 segmentos, y 6 terguitos metasomales visibles 2

Machos: antena con 13 segmentos, y 7 terguitos metasomales visibles 8

2(1) Glosa larga, en reposo alcanzando o sobrepasando el margen posterior del S2, y tan larga como dos o tres veces la longitud del ojo 3

- Glosa corta, no alcanzando el margen posterior del S2, su longitud menos de dos veces la del ojo

3(2) Cabeza y tórax, azul verdoso oscuro o púrpura oscuro; ala anterior con la célula medial (M), no más oscura que el resto del ala E. mexicana (MocsárY)

- Cabeza y tórax oscuro; alas anteriores con la célula medial oscurecida respecto al resto del ala E. surinamensis (LinnaEus) 
4(2) T3 con integumento negro, púrpura, azul o verde oscuro, y/o con la mitad de la superficie con sedas negras y la otra mitad blanquecinas ........................................................... 5

- $\quad$ T3 con integumento color latón, cobre, amarillo verdoso o escarlata ............................ 7

5(4) Cabeza y tórax negros, pero puede presentar algo de azul (T2-6 azul o púrpura verdoso, con pelos amarillos: clípeo con depresiones sobre ambos lados de la elevación media longitudinal) E. rugosa (FRIESE)

Cabeza y tórax azul brillante, púrpura o verde amarillento ....................................... 6

6(5) Mandíbula con integumento azul verdoso en su tercio basal, al igual que el resto del área facial; escuto y escutelo con pubescencia abundante pero no densa

E. caerulescens (Lepeletier de SAINT FARGEAU)

Mandíbula en su tercio basal con integumento casi negro, sólo con un poco de azul oscuro; escuto y escutelo con pubescencia negra muy abundante y densa (escutelo en algunos ejemplares con integumento azul más oscuro que en el escuto, pero con iridiscencia púrpura)

E. micheneri sp. n.

7(4) Clípeo con dos elevaciones longitudinales sublaterales (o crestas) parte media no elevada, sin puntos y pulida ..................................................................... E. concava (FrIESE)

Clípeo con dos elevaciones longitudinales, y una tercera medial (T2-6 color latón o cobre, con pelos amarillos) E. mussitans (FABRICIUS)

8(1) Cabeza, tórax y metasoma de similar color, usualmente azul o verde oscuro 9

- Cabeza y tórax, diferente en coloración que el metasoma, éste usualmente con el T1 oscuro y T2-5 con pubescencia amarilla y brillo dorado (puede presentar iridiscencia de azul o púrpura)

9(8) Area facial, tórax y metasoma con integumento de similar color, entre verde y azul verdoso; pubescencia blanquecina sobre área genal y los lados del tórax E. caerulescens (Lepeletier de SAINT Fargeau)

Area facial con integumento verde o verde azuloso, en contraste con el resto del cuerpo con integumento azul oscuros e iridiscencia púrpura; pubescencia negra sobre área genal y los lados del tórax E. micheneri sp. n.

10(8) Glosa larga que en reposo alcanzando a sobrepasa el S2 .......................................... 11

Glosa corta que en reposo, no alcanza el S2 ......................................................... 13

11(10) Pubescencia del vértex y mitad anterior del mesoscuto blanquecina

E. pallida (KIMSEY)

Pubescencia del vértex oscura en contraste con el color pardo o pardo claro de la mitad anterior del mesoescuto 12

12(11) Ala anterior oscurecida, con la célula medial (M) de color similar que el resto del ala; S8 prolongándose en una sola proyección apical aguda, en vista lateral

E. mexicana (MocsÁRY)

Alas anteriores con la célula medial oscurecida, respecto al color del resto del ala; E8 terminado en dos proyecciones apicales agudas, en vista lateral 
13(9) Clípeo con dos elevaciones longitudinales sublaterales fuertes; tibia posterior con la superficie externa oscura como el resto de la misma estructura (con un poco de brillo metálico) .....

- Clípeo sin elevaciones longitudinales sublaterales fuertes; tibia posterior con la superficie externa pardo rojizo E. rugosa (FRIESE)

14(13) Clípeo con una área cóncava sin puntos, entre las dos elevaciones longitudinales sublaterales; tibia media con el cepillo de pelos poco desarrollado E. concava (FRIESE)

Clípeo con una elevación media longitudinal, entre las dos elevaciones sublaterales; tibia media con el cepillo de pelos bien desarrollado E. mussitans (FABRICIUS)

\section{Acknowledgements}

For the loan of the specimens used in this description we thank to José Luís Navarrete and Hugo Fierros, of the Centro de Estudios de Zoología, CUCBA, Universidad de Guadalajara, while additional specimens were provided by Charlotte Skov. Partial support for this work was provided by National Science Foundation grant EF-0341724 (to M. S. EnGEL). This is a contribution of the Division of Entomology, University of Kansas Natural History Museum.

\section{References}

Dressler, R. L. 1967: Why do euglossine bees visit orchid flowers? - Atas Simpósio sôbre a Biota Amazónica (Zoologia) 5: 171-180.

Dressler, R. L. 1968: Observations on orchids and euglossine bees in Panama and Costa Rica. - Revista de Biología Tropical 15 (1): 143-183.

EngeL, M. S. 1999: The first fossil Euglossa and phylogeny of the orchid bees (Hymenoptera: Apidae; Euglossini). - American Museum Novitates 3272: 1-14.

EngeL, M. S. 2001: A monograph of the Baltic amber bees and evolution of the Apoidea (Hymenoptera). - Bulletin of the American Museum of Natural History 259: 1-192.

Kimsey, L. S. 1980: The behaviour of male orchid bees (Apidae, Hymenoptera, Insecta) and the question of leks. - Animal Behaviour 28 (4): 996-1004.

Kimsey, L. S. 1982: Systematics of bees of the genus Eufriesea (Hymenoptera, Apidae). - University of California Publications in Entomology 95: 1-125.

Michener, C. D. 2007: The Bees of the World [2nd Edition]. - Pp. xiv + [i] + 952, 20 pls. - Baltimore: John Hopkins University Press.

Moure, J. S. 1965: Some new species of euglossine bees (Hymenoptera: Apidae). - Journal of Kansas Entomological Society 38 (3): 266-277.

Ramírez, S.; Dressler, R. L. \& Ospina, M. 2002: Abejas euglosinas (Hymenoptera: Apidae) de la Región Neotropical: Listado de especies con notas sobre su biología. - Biota Colombiana 3 (1): 7-118.

Roubik, D. W. \& Hanson, P. E. 2004: Abejas de orquídeas de la América tropical: Biología y guía de campo. - Pp. 370 - Santo Domingo de Heredia: Instituto Nacional de Biodiversidad.

Authors' addresses:

Dr. R. Ayala

Estación de Biología Chamela

Instituto de Biología, UNAM

Apartado Postal 21

San Patricio

Jalisco, 48980, México

\section{Subject editor:}

Prof. Dr. Michael S. Engel

Prof. Dr. H. H. Dathe

Division of Entomology (Paleoent.)

Natural History Museum

1501 Crestline Drive - Suite 140

University of Kansas

Lawrence, Kansas 66049-2811, United States 